\title{
ANALISIS POTENSI HASIL PERIKANAN LAUT TERHADAP KESEJAHTERAAN PARA NELAYAN DAN MASYARAKAT DI KABUPATEN LAMONGAN
}

\author{
*(Mohammad Yaskun, Edie Sugiarto \\ Fakultas Ekonomi \\ Universitas Islam Lamongan
}

\begin{abstract}
ABSTRAK
Kabupaten Lamongan adalah salah satu Kabupaten di Jawa Timur yang terletak

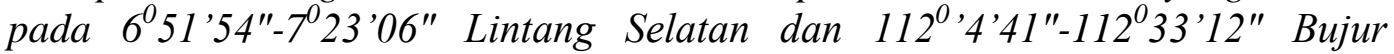
Timur. Fakta tersebut menunjukkan bahwa prospek pembangunan perikanan dan kelautan Kabupaten Lamongan dinilai sangat cerah dan menjadi salah satu kegiatan ekonomi yang strategis. Sumberdaya ikan yang hidup di wilayah perairan Kabupaten Lamongan dinilai memiliki tingkat keragaman hayati (biodiversity) paling tinggi. Tujuan dari penelitian ini adalah; (a) Untuk mengetahui potensi hasil perikanan laut terhadap kesejahteraan para nelayan dan masyarakat di Kabupaten Lamongan tahun 2016, (b) Untuk mengetahui Kontribusi hasil perikanan laut terhadap kesejahteraan para nelayan dan masyarakat di Kabupaten Lamongan. Metode yang digunakan dalam penelitian ini adalah studi deskriptif dengan pendekatan studi literatur. Hasil dari penelitian ini adalah jumlah nelayan di Kabupaten Lamongan adalah 17.892 orang, yang dibagi dalam dua golongan yaitu nelayan buruh 14.166 orang dan nelayan juragan atau pemilik 3.726 orang. Jumlah armada tangkap 3.263 buah dan 3.726 buah alat tangkap serta lima pusat pendaratan ikan (PPI). Pada tahun 2014 produksi perikanan tangkap laut di Kabupaten Lamongan 71.553 ton. Pada tahun 2015 produksi perikanan tangkap laut meningkat menjadi 72.346 ton dengan nilai sebesar Rp. 940.041.822.000. Kontribusi hasil perikanan laut terhadap kesejahteraan para nelayan dan masyarakat di kabupaten Lamongan adalah dengan meningkatnya jumlah produktifitas perikanan memberikan pengaruh positif bagi masyarakat khususnya nelayan dalam pemenuhan kebutuhannya. Hal itu tercermin dari banyaknya UMKM olahan ikan di kecamatan Brondong dan Kecamatan Paciran sebanyak 456 UMKM dari total UMKM olahan ikan di kabupaten Lamongan sebanyak 683 UMKM atau 67\% UMKM olahan ikan berada di pesisir pantai utara. Beberapa produk olahan hasil laut adalah ikan asap, tepung ikan, abon, petis, terasi, pindang, bakso, dan kupas rajungan.
\end{abstract}

Kata kunci : Potensi, Hasil Laut, Kabupaten Lamongan.

\section{PENDAHULUAN}

Kabupaten Lamongan adalah salah satu Kabupaten di Jawa Timur yang terletak 6051'54"-7023'06" Lintang Selatan dan 1120'4'41"-
112033'12" Bujur Timur. Fakta tersebut menunjukkan bahwa prospek pembangunan perikanan dan kelautan Kabupaten Lamongan dinilai sangat cerah dan menjadi 
salah satu kegiatan ekonomi yang strategis. Sumberdaya ikan yang hidup di wilayah perairan Kabupaten Lamongan dinilai memiliki tingkat keragaman hayati (bio-diversity) paling tinggi. Di wilayah perairan laut Lamongan terdapat beberapa jenis ikan bernilai ekonomis tinggi antara lain : tuna, kerapu, udang, tongkol, tenggiri, kakap, cumi-cumi dan rahungan. Namun, sayangnya potensi lautan yang sangat luas ini belum dimaksimalkan sebaik mungkin.

Pada tahun 2014 produksi perikanan tangkap laut di Lamongan mencapai 70.150 ton, pada tahun 2014 produksi perikanan tangkap laut meningkat menjadi sebesar 71.553 ton, dan pada tahun 2015 produksi perikanan tangkap laut meningkat menjadi sebesar 72.346 ton. Industri perikanan didukung oleh pelabuhan perikanan nusantara Brondong yang berskala regional. Usaha penangkapan ikan laut di Kabupaten Lamongan terpusat di perairan Laut Jawa pada wilayah Kecamatan Brondong dan Kecamatan Paciran yang memiliki 5 (lima) Tempat Pendaratan Ikan, yaitu mulai dari arah timur ke barat (Weru, Kranji, Brondong, Labuhan dan Lohgung).

\section{METODE PENELITIAN}

Penelitian ini tergolong sebagai penelitian terapan (applied research) yang diaplikasikan pada bidang perikanan. Menurut Kuncoro (2004), penelitian terapan merupakan penelitian yang menyangkut aplikasi teori untuk memecahkan masalah tertentu. Metode yang digunakan dalam penelitian ini adalah melakukan studi literatur dan studi lapangan serta melakukan FGD. Sedangkan data yang dikumpulkan adalah data kuantitatif dan kualitatif yang terkait dengan hasil perikanan laut di Kabupaten Lamongan.

Metode pengumpulan data dilakukan dengan wawancara terstruktur, wawancara mendalam dan Focus Group Discussion (FGD) untuk memperoleh data primer. Wawancara terstuktur dimaksudkan untuk memperoleh data kuantitatif. Sedangkan wawancara mendalam dan FGD dimaksudkan untuk memperoleh data/informasi yang detail tentang potensi pengembangan hasil laut. Dalam proses wawancara dan FGD akan digunakan alat perekam gambar dan suara sehingga memungkinkan menangkap sebanyak mungkin data/informasi yang disampaikan oleh repsonden atau nara sumber. Data sekunder akan dikumpulkan menggunakan teknik dokumentasi, yaitu memanfaatkan referensi yang terkait dengan bahasan yang dikaji.

\section{HASIL DAN PEMBAHASAN}

Berdasarkan data Dinas
Perikanan Provinsi Jawa Timur bahwa Jawa Timur merupakan bagian dari salah satu propinsi di Indonesia, mempunyai panjang pantai sekitar $16.000 \mathrm{~km}$ dengan produksi ikan laut mencapai 288.816 ton. Jawa Timur memiliki 79 pulaupulau kecil yang terpusat di Kepulauan Madura. Jumlahtersebut merupakan $0,44 \%$ dari jumlah seluruh pulau yang ada di wilayah Indonesia. Dari produksi perikanan di Jawa Timur tersebut, pada tahun 2015 Kabupaten Lamongan memiliki produksi ikan laut sebesar 72.346 ton yang berasal dari 5 Pangkalan Pendaratan Ikan (PPI) yang ada di Kabupaten Lamongan dengan nilai sebesar Rp. 940.041.822.000. 
Tabel 1. Produksi Perikanan Sektor Laut menurut Pelabuhan Pelelangan Ikan Tahun 2015

\begin{tabular}{|c|l|r|}
\hline No & \multicolumn{1}{|c|}{$\begin{array}{c}\text { Pelabuhan } \\
\text { (PPI) }\end{array}$} & \multicolumn{1}{c|}{$\begin{array}{c}\text { Produksi } \\
\text { (Ton) }\end{array}$} \\
\hline 1 & Lohgung & 392,3 \\
\hline 2 & Labuhan & 773,9 \\
\hline 3 & Brondong & $64.326,0$ \\
\hline 4 & Kranji & $2.609,8$ \\
\hline 5 & Weru & $4.244,0$ \\
\hline & Jumlah & $\mathbf{7 2 . 3 4 6}$ \\
\hline
\end{tabular}

Sumber : Dinas Perikanan dan Kelautan Kab. Lamongan

Produksi perikanan tangkap dari perairan laut yang didaratkan di Kabupaten Lamongan secara garis besar terdiri dari kelompok ikan elagis, kelompok ikan demersal dan kelompoknon-ikan (Crustacea dan Mollusca). Produksi ikan ekonomis penting pada kelompok ikan pelagis didominasi oleh 6 jenis ikan,yakni: Ikan layang, lemuru, tenggiri, tuna, cakalang dan tongkol. Sementara, untuk kelompok ikan demersal, produksi ikan yang bernilai ekonomi penting didominasi oleh jenis ikan manyung, kerapu, kurisi, swanggi/mata besar dan layur. Selanjutnya, untuk kelompok nonikanyang bernilai ekonomis penting, produksinya didominasi olehjenis: rajungan, kepiting dan udang putih (Crustacea) serta remis, kerang darah dan cumi-cumi (Mollusca). Berikut data produksi perikanan laut menurut jenis ikan tahun 2015 :

Tabel 2. Data Produksi Perikanan Laut Menurut Jenis Ikan Tahun 2015

\begin{tabular}{|c|l|r|}
\hline \multirow{2}{*}{ No } & \multicolumn{1}{|c|}{ Jenis Ikan } & $\begin{array}{c}\text { Jumlah Produksi } \\
\text { (Ton) }\end{array}$ \\
\hline 1 & Swanggi/matabesar & $16,338.0$ \\
\hline 2 & Kurisi & $12,131.4$ \\
\hline 3 & Kuningan & $6,564.5$ \\
\hline 4 & Kapasan & $5,832.1$ \\
\hline 5 & Biji Nangka & $3,241.3$ \\
\hline 6 & Tembang & $2,839.7$ \\
\hline 7 & Peperik/pirik & $2,400.3$ \\
\hline 8 & Layang & $2,349.0$ \\
\hline 9 & Cumi-cumi & $1,989.4$ \\
\hline 10 & Tongkol Krai & $1,865.4$ \\
\hline 11 & Lain-lain & $16,794.9$ \\
\hline & Total & $\mathbf{7 2 , 3 4 6 . 0}$ \\
\hline
\end{tabular}

Sumber : Dinas Perikanan dan Kelautan Kab. Lamongan 
Peraturan Daerah Kabupaten Lamongan Nomor 19 Tahun 2010 tentang Retribusi Tempat Pelelangan Pasal 1 angka 19 yang mendefinisikan "nelayan adalah orang yang mata pencaharian adalah melakukan penangkapan ikan". Dalam peraturan Bupati Lamongan Nomor 33 Tahun 2013 tentang Petunjuk Pelaksanaan Izin Usaha Perikanan di Kabupaten Lamongan Pasal 1 angka 7 yang mendefinisikan "nelayan adalah orang yang mata pencaharian melakukan penangkapan ikan". Jumlah nelayan di Kabupaten
Lamongan adalah 17.892 orang, yang dibagi dalam dua golongan yaitu nelayan buruh 14.166 orang dan nelayan juragan atau pemilik 3.726 orang. Jumlah armada tangkap 3.263 buah dan 3.726 buah alat tangkap serta lima pusat pendaratan ikan, yaitu; Lohgung, Labuhan, Brondong, Kranji dan Weru. Sehingga Kabupaten Lamongan mempunyai industri perikanan tangkap terbesar di Jawa Timur. Berikut data jumlah nelayan per desa tahun 2015.

Tabel 3. Data Jumlah Nelayan Per Desa Tahun 2015

\begin{tabular}{|c|l|r|r|r|}
\hline No & \multicolumn{1}{|c|}{ Desa } & $\begin{array}{c}\text { Nelayan } \\
\text { Pemilik }\end{array}$ & $\begin{array}{c}\text { Nelayan } \\
\text { Penggarap }\end{array}$ & Jumlah \\
\hline 1 & Paloh & 118 & 755 & 873 \\
\hline 2 & Warulor & 144 & 40 & 184 \\
\hline 3 & Sidokumpul & 172 & 388 & 560 \\
\hline 4 & Weru & 424 & 630 & 1054 \\
\hline 5 & Kemantren & 198 & 279 & 477 \\
\hline 6 & Sidokelar & 16 & 96 & 112 \\
\hline 7 & Banjarwati & 93 & 696 & 789 \\
\hline 8 & Kranji & 138 & 1,023 & 1161 \\
\hline 9 & Tunggul & 37 & 107 & 144 \\
\hline 10 & Paciran & 519 & 623 & 1142 \\
\hline 11 & Kandangsemangkon & 271 & 2,901 & 3172 \\
\hline 12 & Blimbing & 343 & 3,914 & 4257 \\
\hline 13 & Brondong & 115 & 974 & 1089 \\
\hline 14 & Sedayulawas & 64 & 148 & 212 \\
\hline 15 & Brengkok & 53 & 58 & 111 \\
\hline 16 & Labuhan & 327 & 1,013 & 1340 \\
\hline 17 & Lohgung & 694 & 521 & 1215 \\
\hline & Total & $\mathbf{3 . 7 2 6}$ & $\mathbf{1 4 . 1 6 6}$ & $\mathbf{1 7 . 8 9 2}$ \\
\hline
\end{tabular}

Sumber : Dinas Perikanan dan Kelautan Kab. Lamongan 
Usaha perikanan tangkap sendiri merupakan usaha yang membutuhkan keterkaitan antar komponen tertentu agar hasil yang diperoleh dapat maksimal, jika komponen yang menjadi syarat dalam usaha perikanan tangkap tidak dipenuhi maka produksi yang dihasikan tidak akan maksimal.

Komponen-komponen yang berperan dalam sistem perikanan tangkap adalah, masyarakat, sarana produksi, proses produksi, prasarana pelabuhan, sumberdaya ikan, pengolahan, pemasaran dan aspek legal. Inimenunjukkan bahwa dalam suatu usaha perikanan tangkap hubungan antar indikator tersebut akan sangat menentukan tingkat keberhasilan usaha penangkapan.

Kebijakan

pembangunan

perikanan pada masa yang akan datang hendaknya didasarkan pada landasan pemahaman yang benar tentang peta permasalahan pembangunan perikanan itu sendiri, yaitu mulai dari permasalahan mikro sampai pada permasalahan di tingkat makro yang mengarah pada pemberdayaan masyarakat nelayan. Permasalahan mikro yang dimaksudkan adalah persoalan internal masyarakat nelayan menyangkut aspek sosial budaya seperti pendidikan, mentalitas, dan sebagainya. Aspek ini yang mempengaruhi sifat dan karakteristik masyarakat nelayan dan petani ikan. Sifat dan karakteristik tersebut dipengaruhi oleh jenis kegiatan usaha seperti usaha perikanan tangkap, usaha perikanan tambak, dan usaha pengolahan hasil perikanan. Kelompok masyarakat ini memiliki sifat unik berkaitan dengan usaha yang dilakukannya. Karena usaha perikanan sangat bergantung pada musim, harga dan pasar maka sebagian besar karakter masyarakat pesisir (khususnya nelayan dan petani ikan) tergantung pada faktorfaktor tersebut, yaitu: (1) kehidupan masyarakat nelayan dan petani ikan menjadi amat tergantung pada kondisi lingkungan atau rentan pada kerusakan khususnya pencemaran atau degradasi kualitas lingkungan; (2) kehidupan masyarakat nelayan sangat tergantung pada musim, ketergantungan terhadap musim ini akan sangat besar dirasakan oleh nelayan-nelayan kecil; (3) persoalan lain dari kelompok masyarakat nelayan adalah ketergantungan terhadap pasar, hal ini disebabkan komoditas yang dihasilkan harus segera dijual untuk memenuhi kebutuhan hidup sehari-hari atau membusuk sebelum laku dijual. Karakteristik ini mempunyai implikasi yang sangat penting yaitu masyarakat nelayan sangat peka terhadap fluktuasi harga. Perubahan harga sekecil apapun sangat mempengaruhi kondisi sosial masyarakat nelayan. Namun demikian di balik ketiga persoalan tersebut sebenarnya ada persoalan yang lebih mendasar yaitu persoalan sosial dalam konteks makro menyangkut ketergantungan sosial (patron client). Karena faktor kelemahan yang dimiliki sebagian besar nelayan, mereka tidak bisa menghindari adanya sistem sosial yang tanpa atau disadari menjeratnya ke dalam "lingkaran setan" kemiskinan. Sistem sosial ini sudah begitu melembaga pada masyarakat nelayan. Persoalan inilah yang seharusnya menjadi fokus perhatian pemerintah dalam melakukan pemberdayaan nelayan dan pembudidaya ikan. 
Semestinya ada instrumen kebijakan yang mampu secara efektif mengurangi (kalau tidak dapat menghilangkan) sistem sosial yang tidak memungkinkan nelayan kecil keluar dari lingkaran kemiskinan. Seperti menciptakan skenario baru model-model pembiayaan untuk pemberdayaan nelayan dan pembudidaya ikan melalui penguatan kelembagaan dan kemampuan bisnis masyarakat pesisir menjadi sangat mendesak untuk diimplementasikan.

Ikan merupakan salah satu sumber protein hewani yang banyak dikonsumsi masyarakat, mudah diperoleh dan harganya relatif murah. Namun ikan cepat mengalami proses pembusukan dan penurunan mutu dikarenakan daging ikan mempunyai kadar air yang cukup tinggi, pH netral, teksturnya lunak dan kandungan gizinya tinggi. Sehingga menjadi medium yang sangat baik untuk pertumbuhan bakteri. Ikan merupakan sumber pangan hewani yang mempunyai berbagai keunggulan karena kandungan ikan sangat komplek. Hanya ikan yang bermutu baik yang memberikan manfaat kesehatan secara optimal. Ikan yang diawetkan dengan proses pembekuan dan dikonsumsi lewat dari masa penyimpanan akan meningkatkan kadar histamin. Kandungan histamin pada ikan memiliki efek psikoaktif dan vasoaktif. Efek psikoaktif menyerang sistem saraf transmiter manusia, sedangkan efek vasoaktifnya menyerang sistem vaskular. Histamin dapat menyebabkan migren dan meningkatkan tekanan darah. Bakteri yang berperan dalam proses pembusukan ikan antara lain Vibrio, Staphylococcus, Salmonella dan Escherichia coli. Oleh karena itu perlu adanya pengolahan ikan, sehingga ada penambahan nilai pada ikan. Berikut data jumlah UMKM olahan ikan perkecamatan.

Tabel 4. Jumlah UMKM Olahan Ikan Per Kecamatan

\begin{tabular}{|c|c|c|c|c|c|c|c|c|c|c|c|c|c|c|c|}
\hline No & Kecamatan & Kerupuk & Asap & Abon & Petis & Asin & Terasi & $\begin{array}{l}\text { Otak- } \\
\text { Otak }\end{array}$ & Pindang & Bakso & $\begin{array}{c}\text { Rumput } \\
\text { Laut }\end{array}$ & Snack & Presto & \begin{tabular}{|c|} 
Kupas \\
Rajungan
\end{tabular} & Jumlah \\
\hline 1 & Glagah & 10 & 1 & 1 & 1 & & & & & & & & & & 13 \\
\hline 2 & Deket & & 73 & & & 22 & 25 & 1 & & & & & & & 121 \\
\hline 3 & Karangbinangun & & & & & & 23 & & & & & & & & 23 \\
\hline \begin{tabular}{|l|}
4 \\
\end{tabular} & Lamongan & & 13 & & & 17 & & 5 & & & & & & & 35 \\
\hline 5 & Kalittengah & 1 & & & & & & & & & & & & & 1 \\
\hline 6 & Turi & 1 & 20 & & & 2 & & 6 & & & & & & & 29 \\
\hline 7 & Karanggeneng & 5 & & & & & & & & & & & & & 5 \\
\hline 8 & Brondong & 21 & 28 & 5 & 10 & 59 & 3 & & 58 & 6 & 1 & 2 & 11 & & 204 \\
\hline 9 & Paciran & 72 & 44 & 2 & 31 & 46 & 13 & & 33 & 3 & & & & 8 & 252 \\
\hline & Total & 110 & 179 & 8 & 42 & 146 & 64 & 12 & 91 & 9 & 1 & 2 & 11 & 8 & 683 \\
\hline
\end{tabular}

Sumber : Dinas Perikanan dan Kelautan Kab. Lamongan 
Seperti halnya produk pangan lainnya, produk perikanan dipandang penting untuk mendapatkan sentuhan konsep OVOP (One Vilage One Product). Beberapa daerah di Indonesia telah dikenal sebagai penghasil setidaknya satu jenis produk khas berbahan baku ikan. Produk ikan Nilam (Singaparna, Tasikmalaya), Amplang Ikan (Tanah Bumbu-Kalimantan Selatan), olahan telur Torani (Majene, Sulbar), Teri (Maringgai, Lampung), Ikan Pari (Tanjung Jabung Barat, Jambi), Kerupuk Udang (Sindang, lndramayu), Selai Patin (Kampar, Riau), cakalang fufu (Bitung, Sulut) merupakan beberapa contoh produk khas daerah yang dapat dikembangkan. Kunci utama kesuksesan pengembangan OVOP produk perikanan terletak pada pengenalan karakter produk serta motivasi subyek pelaksananya.

Kementerian Perindustrian merealisasikan Gerakan OVOP mulai tahun 2008 agar IKM/UKM dapat berkembang dan masuk ke pasaran produk yang Iebih luas. Langkah ini disusun bersama-sama dengan unsur pemerintah terkait lainnya seperti Kementerian Perdagangan, Kementerian Koperasi dan UKM, Deptan, Bappenas, BPPT, Menko Perekonomian, Kementerian Kelautan dan Perikanan (DKP). Depperin telah memetakan beberapa sentra pengembangan pada 80 kabupaten yang secara infrastruktur lebih siap seperti di di Jawa, Bali, NTB, Sumatera Utara dan Sumatera Barat. Sirup markisa dari Gowa, rumput laut (Sumbawa), batik (Pekalongan), mebel kayu (Sumedang), kerajinan kulit (Magetan), tas (Sidoarjo) adalah beberapa contoh produk dan daerah yang yang telah dipetakan. Dana senilai $\mathrm{Rp}$ 58,2 miliar akan dikucurkan terutama untuk peralatankerjadan pelatihan. Syarat produk yang dapat direkomendasikan dalam pengembangan Ovop menyangkut homogenitas produk, lokasi, akses jalan, tata ruang serta komitmen Pemda. Pengusulan daerah yang berniat mengembangkan Ovop akan dilakukan dengan mekanisme bottom up. Depperin selanjutnya akan menyeleksi lokasi tersebut menggunakan beberapa kriteria seperti keunikan khas budaya dan keaslian lokal/originalitas, mutu dan tampilan produk, potensi pasar yang terbuka di dalam dan di luar negeri serta kontinuitas dan konsistensi produksi yang didukung sumber daya lokal.

\section{KESIMPULAN}

Penelitian ini bertujuan untuk mendiskripsikan potensi hasil perikanan laut terhadap kesejahteraan para nelayan dan masyarakat di Kabupaten Lamongan. Dari penelitian ini dapat diuraikan dalam kesimpulan sebagai berikut :

1. Penelitian potensi hasil perikanan laut terhadap kesejahteraan para nelayan dan masyarakat di Kabupaten Lamongan.

Hasil analisis dari rekapitulasi, pada tahun 2013 produksi perikanan tangkap laut di Lamongan mencapai 70.150 ton. Pada tahun 2014 produksi perikanan tangkap laut meningkat menjadi sebesar 71.553 ton. 
Pada tahun 2015 produksi perikanan tangkap laut meningkat sebesar 72.346 ton yang berasal dari 5 Pangkalan Pendaratan Ikan (PPI) yang ada di Kabupaten Lamongan dengan nilai sebesar Rp. 940.041.822.000. Industri perikanan didukung oleh Pelabuhan Perikanan Nusantara (PPN) Brondong yang berskala regional.

2. Kontribusi hasil perikanan laut terhadap kesejahteraan para nelayan dan masyarakat di Kabupaten Lamongan.

Meningkatnya jumlah produktifitas perikanan memberikan pengaruh positif bagi masyarakat khususnya nelayan dalam pemenuhan kebutuhannya. Hal itu tercermin dari banyaknya UMKM Olahan Ikandi kecamatan Brondong dan kecamatan Paciran sebanyak 456 UMKM dari total UMKM olahan ikan di kabupaten Lamongan sebanyak 683 UMKM atau 67\% UMKM olahan ikan berada di pesisir pantai utara. Beberapa produk olahan hasil laut adalah ikan asap, tepung ikan, abon, petis, terasi, pindang, bakso, dan kupas rajungan.

\section{DAFTAR PUSTAKA}

Arif Satria. 2002. Pengantar Sosiologi Masyarakat Pesisir. Jakarta: PT. Pustaka Cidesindo.

Bagong Suyanto \& Karnaji. 2005.Kemiskinan dan

Kesenjangan Sosial: Ketika Pembangunan tak berpihak kepada rakyat miskin.

Surabaya: Airlangga University Press.

Csirke, J. 1988. Small Shoalding Fish Stock. In J.A Gulland, ed. Fish Population Dynamic, 2nd John Willy and Sons, Chechester

Dahuri, R. 2001. Menggali Potensi Kelautan danPerikanan dalam Rangka PemulihanEkonomi Menuju Bangsa Indonesiayang Maju, Makmur dan Berkeadilan.Makalah pada acara temu akrab CivaFPi,tanggal 25 Agustus2001.Bogor.

Dahuri, R. 2002.Modul Sosialisasi dan Orientasi Penataan Ruang Pesisir dan PulauPulau Kecil. S.l. : Departemen Kelautan dan Perikanan. Jakarta.

Dinas Perikanan dan Kelautan Provinsi Jawa Timur. 2014. Statistik Perikanan Tangkap Provinsi Jawa Timur Tahun 2013.

Dinas Perikanan dan Kelautan Kabupaten Lamongan. 2013.Laporan Tahunan Bidang Perikanan Budidaya.

Direktorat Jenderal Perikanan Budidaya, 2012. Statistik Ekspor Hasil Perikanan tahun 2014. Departemen Kelautan dan Perikanan. Jakarta

Kelautan dan Perikanan Dalam Angka tahun 2015. Kementerian Kelautan dan Perikanan. Jakarta.

Keputusan Menteri Kelautan dan Perikanan Republik Indonesia Nomor Kep. 18/Men/2011 tentang Pedoman Umum Minapolitan. 
Kusnadi. 2006. Filosofi Pemberdayaan Masyarakat Pesisir. Bandung, Humaniora. Lamongan Dalam Angka. 2015.

Lubis, Ernani. 2012. Pelabuhan Perikanan. Bogor. IPB Press.

Ma'ruf, W.F. \& Agus H.P. Perikanan Laut Melalui Penerapan UU 32/2004. Makalah Semiloka "Konsep

PembangunanPerikanan dan Kelautan Propinsi Jawa Tengah dalam rangka Implementasi $U U$ 32/2004".Semarang: 25-27 Maret.

Murachman. 1987. Pengetahuan Hasil-hasil Perikanan. Fakultas Perikanan Universitas Brawijaya. Malang.

Pemerintah Kabupaten Lamongan. 2015. Gambaran Umum Kabupaten Lamongan.

Peraturan Bupati Lamongan Nomor 33 Tahun 2013 tentang Petunjuk Pelaksanaan Izin Usaha Perikanan di Kabupaten Lamongan.
Peraturan Daerah Kabupaten Lamongan Nomor 2 Tahun 2010 tentang Kepelabuhan di Kabupaten Lamongan.

Peraturan Daerah Kabupaten Lamongan Nomor 19 Tahun 2010 tentang Retribusi Tempat Pelelangan.

Peraturan Daerah Kabupaten Lamongan Nomor 27 Tahun 2010 tentang Retribusi Izin Usaha Perikanan.

Peraturan Daerah Kabupaten Lamongan Nomor 15 Tahun 2011 tentang Rencana Tata Ruang Wilayah Kabupaten Lamongan Tahun 2011-2031.

Supriharyono. 2000. The Problem of Coastal And Marine Resources Management in Indonesia. Journal of Coastal Development Vol 4 No.1, October 2000 P: 41-49.

Sukmadinata, N.S. 2005. Metode Penelitian Penelitian. Cetakan ke 7. Bandung : Remaja Rosdakarya.

Sadly, H. 1980. Sosiologi untu masyarakat Indonesia. Jakarta: PT. Pembangunan. 